\title{
The Study Trees Potential for Forest in Universitas Lancang Kuning Pekanbaru
}

\author{
Fitridawati $^{1}$, Lusi Dwi Putri ${ }^{2}$, Marta Dinata ${ }^{3 *}$ \\ 1,2 Department of Civil Engineering, Faculty of Engineering, Universitas \\ Lancang Kuning, Indonesia \\ ${ }^{3}$ Department of Biology Education, FKIP Universitas Lancang Kuning, \\ Indonesia \\ Email: fitridawati@unilak.ac.id, lusidwiputri@unilak.ac.id, \\ martadinata@unilak.ac.id
}

\begin{abstract}
The location of the study of Potential tree species for Peripheral Forest Development is determined by Lancang Kuning University, which is on Yos Sudarso road KM 8 Rumbai Pekanbaru, which is a fragmented habitat. The method used is census through measurement of area, structure observation, population enumeration, measurement of three dimensions. Calculating tree species diversity ( $\left.\mathrm{H}^{\prime}\right)$, Assessing the suitability criteria of a type of tree for each type of green edge path area refers to the method of analyzing an integrated research plan, the important value index for the highest vegetation is acacia (Acacia auriculiformis) with a value amounting to 73.11. Acacia (Acacia auriculiformis) type of tree is less suitable. This is because the population is too high, where the debris that falls hard to decompose causes a thick pile when trampled slipperily and endangers safety, which eventually leaves litter accumulation causing soil conditions on the slopes to become soft because it is moist and has the potential to become landslides.
\end{abstract}

Keywords: Forests, area types, vegetation structure and potential tree species.

\section{Introduction}

Forest is an ecosystem that has a diversity of flora and fauna. This forest ecosystem is poor in nutrients when compared to temperate climate forests. However, according to Basuki, T. M, Dwi, B.H and Sukresno, 2008, forests are an ecosystem in the form of overlays, land containing biological natural resources dominated by trees in the fellowship of their natural environment, which are inseparable from one another. While the urban forest is a stretch of land that grows compact trees and meetings in urban areas both on state land and land rights, which are designated as urban forest by authorized officials (PP No. 63 of 2002 concerning urban forest Article 1 paragraph 2).

According to Tinambunan (2006), the form of urban forests, in general, are (a) Green Pathways, (b) City Parks, (c) Gardens and Pages, (d) Botanical Gardens, (e) Great Forests and Zoos and (f) Protected forest. According to Yulianto (2009), this type of plant can suppress air pollution, absorb and absorb dust, reduce odour, reduce noise, reduce soil erosion, windbreaks and rain through: Watery leaves can reduce sound. Branches and twigs move and vibrate can absorb, envelop the sound, as well as thick leaves blocking 
the sound and thin leaves, can reduce sound. Leaf trichomes can absorb dust grains, through electrostatic and electromagnetic movements. Gas exchange through leaf mouth. The aroma of flowers and leaves reduces odour. Branching and twigs and their leaves can withstand wind and rainfall. The Spread of roots can bind the soil from erosion. Branches that are twisted and thorny can block human interference. The shape and texture of leaves influence the current and direction of local turbulence. Leaf surface roughness has the potential for precipitation of lead $(\mathrm{Pb})$ and zinc $(\mathrm{Zn})$. Leaves and hairy twigs will be able to absorb and intercept lead $(\mathrm{Pb})$ and zinc $(\mathrm{Zn})$ more, compared to the slippery branches. Thus the existence of a type of plant as vegetation has a very important role in each type of green edge lane area. By selecting an appropriate and appropriate type with the designation of the type of green edge lane area, the existence of the forest will function optimally.

This research is a follow-up study, based on research data obtained previously in 2015 when viewed from the species diversity value $\left(\mathrm{H}^{\prime}\right)$ of tree vegetation in the Lancang Kuning university forest area, it was seen that species diversity in the green edge area was moderate. The highest diversity value is 1.62 . In the species diversity index criteria $\left(\mathrm{H}^{\prime}\right)$ it falls into the medium category.

Based on the results of the overall analysis of the composition and structure of tree vegetation in the green rim area in March 2019 it is known that tree-level vegetation is dominated by acacia (Acacia auriculiformis) with a value of 75.15 with an important value index for the highest tree vegetation at each observation station. Asmayannur et al (2012) said the level of mastery of a type of a location was determined from the results of comparison of its importance so that it can be clearly known the level of mastery through the INP obtained. This level of mastery illustrates the ability of a species to be able to develop and survive against certain habitat conditions, based on the above research theory can be interpreted that the type of Acacia auriculiformis has a high degree of mastery of tree vegetation compared to other types.

In general, trees play a role in absorbing $\mathrm{CO}_{2}$ and removing $\mathrm{O}_{2}$, but individually that each type of tree has different characteristics and functions such as aesthetics, absorbs pollutants, dampens noise, absorbs carbon, absorbs and dispels odours, reduces the danger of acid rain and overcoming stagnant water or as a water absorber in each region.

\section{Experimental Sections}

\section{Research Procedure and Data Analysis}

The stages of research activities are as follows: 1. Coordinate with relevant agencies in the city of Pekanbaru and at the same time collect secondary data used as the basis and support in the research activities, namely: Pekanbaru spatial plan data (RTW), Central Regulations and Regional Regulations concerning green edge lane, and monograph from Lancang Kuning University. 2. Conduct an inventory and dimension 
measurement of all tree species that have reached $\varnothing \geq 10 \mathrm{~cm}$. 3 . Identify and characterize each tree. 4. Identify, and characteristics of each tree.

\section{Data analysis}

1. Analysis of descriptions by recording each type, diameter, width and height of tree canopies and parts of trees (leaves, flowers and fruit) divided into 4 stations using the stratified random sampling method and then identifying refers to (Heyne, 1987) and (Samingan, 1982).

2. Calculating the diversity of tree species $\left(\mathrm{H}^{\prime}\right)$ using the Shannon Weinner formula according to Barbour et al. (1987) in Yulianto (2009), namely:

$$
H^{*}=-\sum_{i}^{i}\left[\frac{n i}{N} \ln \frac{n i}{N}\right]
$$

Where:

$\mathrm{H}$ ': Diversity index of Shannon Weiner;

this: Number of population of a type and N: Total population of all types

3. Reviewing the suitability criteria of a type of tree for each type of urban forest area refers to the method of analyzing an integrated research plan (Samsoedin, 2009), with measured tree parameters: (a) Tree diameter and height; (b) Canopy model, leaf shape, branch shape and stem shape; (c) Tree condition; (d) Power grows on critical land or polluted land and land with high groundwater conditions (situ and riverbanks); (e) Tree phenology (fruit and flowers) Based on the above parameters, an assessment of "Suitability of tree species of each type of urban forest area" is prepared with the following formula:

$$
K s=(X n+Y n)-Y N
$$

Where :

Ks = The suitability criteria for a tree

$\mathrm{Xn}=$ Number of characteristics of an appropriate tree type for each type of urban forest area

$\mathrm{Yn}=$ The number of characteristics of a tree type that is less appropriate for each type of forest area

city.

The parameters of tree species suitability for each type of green edge lane area found at Lancang Kuning University are presented in Table 1. 
Table. 1 Parameter of Suitability of potential tree types

\begin{tabular}{|c|c|c|}
\hline \multirow{2}{*}{ No. } & \multirow{2}{*}{$\begin{array}{c}\text { Characteristics and Parts of } \\
\text { Tree Phenotype }\end{array}$} & Pekanbaru City Forest \\
\hline & & $\mathbf{X}$ \\
\hline 1. & Fast tree growth & $*$ \\
\hline 2. & The diameter can reach $\geq 10 \mathrm{~cm}$ & $*$ \\
\hline 3. & Sturdy rod & $*$ \\
\hline 4. & Deep and strong rooting & $*$ \\
\hline 5. & Headline & $*$ \\
\hline 6. & Beautiful title & \\
\hline 7. & Leaves break down easily & $*$ \\
\hline 8. & Thick leaves & $*$ \\
\hline 9. & Small leaves & \\
\hline 10. & Hairy leaves & $*$ \\
\hline 11. & Fragrant flowers & \\
\hline 12. & Interest in fauna feed sources & $*$ \\
\hline \multirow[t]{2}{*}{13.} & Fruit feed source for fauna & $*$ \\
\hline & Score & $\mathbf{X n}$ \\
\hline $\mathrm{X}$ & $\begin{array}{l}=\text { Column to write the score of numb } \\
\text { right with the type of Green Side Path }\end{array}$ & acteristics of a tree type are \\
\hline Y & $\begin{array}{l}=\text { Column to write the score of numb } \\
\text { not right with the type of path area of }\end{array}$ & acteristics of a tree type are \\
\hline$*$ & $\begin{array}{l}\text { Is a characteristic of a potential tre } \\
\text { for each type of Green Side Path area. } \\
\text { Source : Samsoedin (2009) }\end{array}$ & uptake that must be owned \\
\hline
\end{tabular}

\section{Results and Discussion}

Data on Plant Vegetation Composition and Structure at Lancang Kuning University

Research on the composition and structure of plant vegetation in the area of the Lancang Kuning Pekanbaru Green Pathway, which was conducted in March 2019, obtained the following results:

Table. 2 Recapitulation of Plant Vegetation Data in the Green Side Path area

\begin{tabular}{|c|c|c|c|c|c|c|c|}
\hline \multirow[t]{2}{*}{ No } & \multirow[t]{2}{*}{ Vegetation } & \multicolumn{4}{|c|}{ Station / individual } & \multirow{2}{*}{$\begin{array}{c}\text { Total } \\
\text { Individual } \\
\end{array}$} & \multirow{2}{*}{$\begin{array}{c}\text { Total } \\
\text { Species }\end{array}$} \\
\hline & & 1 & 2 & 3 & 4 & & \\
\hline 1 & Tree & 138 & 99 & 102 & 104 & 443 & 30 \\
\hline 2 & Pole & 31 & 50 & 38 & 22 & 141 & 22 \\
\hline 3 & Stake & 11 & 27 & 21 & 17 & 76 & 19 \\
\hline 4 & Seedling & 43 & 40 & 34 & 39 & 156 & 22 \\
\hline & & Tot: & & & & 816 & 94 \\
\hline
\end{tabular}

(Source: Primary Data, 2019) 
Comparison of the amount of vegetation data at the tree, pole, stake and seedling level can be seen in the following diagram:

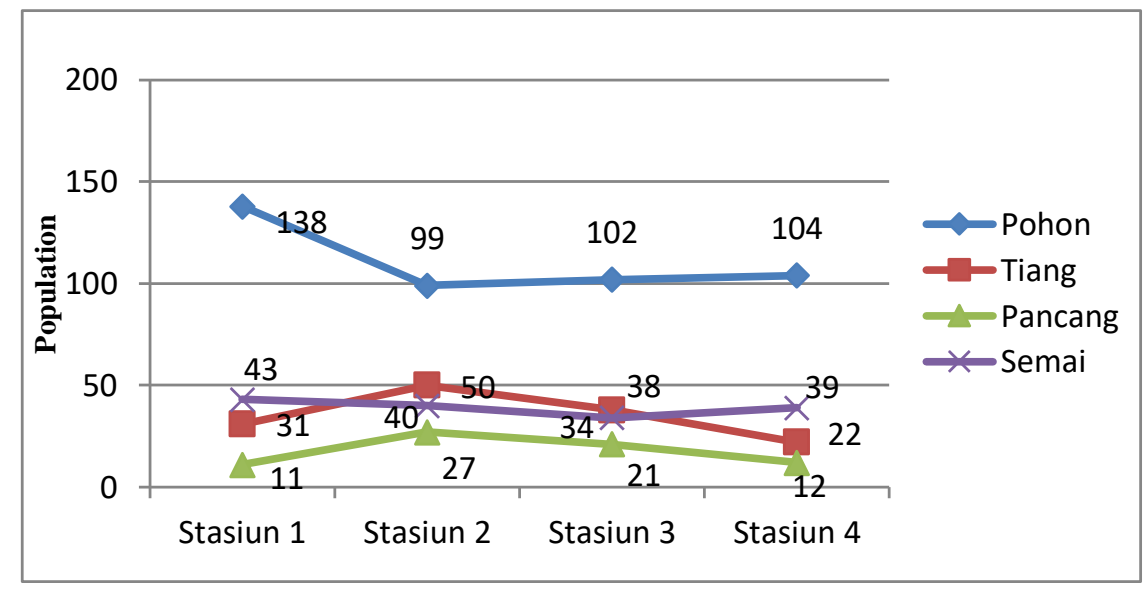

Figure.1 Comparison diagram of the number of vegetation at tree level, poles, stakes, and seedlings

The results of the research that have been carried out, obtained data about the composition and structure of vegetation at the tree, pole, sapling and seedling level in the Lancang Kuning University Pekanbaru Green Pathway area. Tree level vegetation consists of 30 species with a total of 443 individuals, the dominant tree species include: Acacia (Acacia auriculiformis), Mahogany (Swietenia macrophylla), Pulai (Alstonia scholaris), Ketapang (Terminalia catappa), while Duku (Lansium domesticum), Noni (Morinda citrifolia), Trembesi (Samanea saman), Biduri bulan (Calotropis gigantea), Lamtoro (Leucaena leucocephala) and others.

Plant vegetation for the pole level consists of 22 species with 141 individuals, the dominant types of poles include: Angsana (Pterocarpus indicus), Mahogany (Swietenia macrophylla), Durian (Durio zibethinus), while for the species that is small is Kulim (Scrodocarpus borneensis), Matoa (Pometia pinnata), Salam (Syzygium polyanthum), and others.

The sapling vegetation has 19 species with a total of 76 individuals, the types of saplings that dominate include Trembesi (Samanea saman), Angsana (Pterocarpus indicus), Ketapang (Terminalia catappa), Banana (Musa paradisiaca), Pinang (Areca catechu), Mahogany (Swietenia macrophylla), while for the few species found include: Acacia (Acacia auriculiformis), Salam (Syzygium polyanthum), Mangosteen (Garcinia mangostana), Durian (Durio zibethinus), Matoa (Pometia pinnata), and others.

Seedling plant vegetation has 22 species with 156 individuals, the dominant types of seedlings are Salam (Syzygium polyanthum), Ketapang (Terminalia catappa), Agarwood (Aquilaria spp), Palm (Elaeis guineensis), Areca palm (Areca catechu), Fruit wheels (Hura crepitans), while for species that are few found include: Noni (Morinda citrifolia), Pulai (Alstonia scholaris), Sungkai (Peronema canescens), and others. 
If a type of tree is suitable as a vegetation in the Green Edge Path area, then a cross ( $\mathrm{x}$ ) is given on each column of the Lancang Kuning University Green Pathway type as well as the tree type suitability matrix. The highest value index for the highest tree vegetation is acacia (Acacia auriculiformis) with a value of 73.11. Asmayannur et al (2012) said the level of mastery of a type of a location was determined from the results of comparison of its importance so that it can be clearly known the level of mastery through the INP obtained. This level of mastery illustrates the ability of a species to be able to develop and survive against certain habitat conditions, based on the above research theory can be interpreted that the type of Acacia auriculiformis has a high degree of mastery of tree vegetation compared to other types.

Diversity index in tree level vegetation can be seen in Figure 4.1. Based on the picture, it can be seen that the diversity of tree vegetation is classified as moderate as in the criteria determined in the Shanon Wienner formula, Lianah et al. (2013) if the diversity index is less than equal to 3 or more than equal to 1 then diversity is classified as moderate $\left(1 \leq \mathrm{H}^{\prime} \leq 3\right)$.

Acacia (Acacia auriculiformis) type of tree is less suitable. This is because the population is too high, where the serasah which falls hard to decompose causes a thick pile when trampled slipperily and endangers the safety of children. Mismatch of Acacia trees (Acacia auriculiformis) in the green edge area, because the location is a place for field practice where there are many activities, as well as places for pedestrian crossings that are always used, besides the accumulation of thick acacia leaf litter which causes soil conditions the slope becomes soft because it is moist and has the potential to become a landslide. While the vegetation found on the green edge of Lancang Kuning University is generally trees planted at the age of tens of years ago, and there are not a few trees found in each location that has been eaten by age, natural factors (lightning) and irresponsible human hands ( vandalism) so that the physical condition has endangered the safety of visitors and surrounding facilities. One of the results of this study is the arrangement of a matrix of potential tree species that can be used as an alternative choice of vegetation for the construction of strong green edge lanes for anchoring the marginal soil walls.
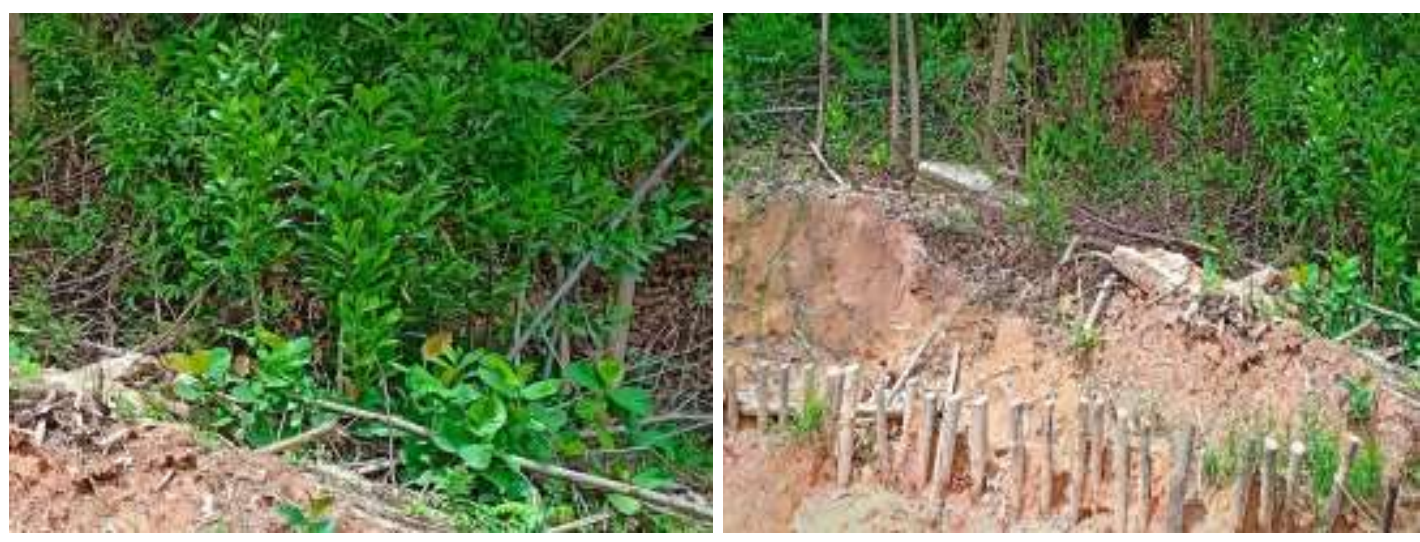

82 IEKSAKTA: Berkala IImiah Bidang MIPA 
Figure 3. Tree (Acacia auriculiformis) Figure 4. Landslide Condition of the Green Pathway

\section{Physical-Chemical Parameters}

Research on the composition and structure of plant vegetation in the green edge area of the University of Lancang Kuning Pekanbaru, which was conducted in March 2019 with an overall area of \pm 6.1 Ha. This research was conducted by dividing the research location into four stations with one station consisting of 6 plots. Based on the research that has been done, the physicochemical parameter data are obtained as follows:

Table 3. Data on Physical-Chemical Parameters in the Suburban Path Area

\begin{tabular}{llcccc}
\hline & Physical- & \multicolumn{4}{c}{ STATION } \\
\cline { 3 - 6 } No & Chemical & $\mathbf{1}$ & $\mathbf{2}$ & $\mathbf{3}$ & $\mathbf{4}$ \\
\hline & Parameters & $0^{\circ} 30^{\prime} 83^{\prime \prime} \mathrm{N}$ & $0^{\circ} 30^{\prime} 89^{\prime \prime} \mathrm{N}$ & $0^{\circ} 30^{\prime} 90^{\prime \prime} \mathrm{N}$ & $0^{\circ} 30^{\prime} 95^{\prime \prime} \mathrm{N}$ \\
1 & Ordinate & $101^{\circ} 27^{\prime} 15^{\prime \prime} \mathrm{E}$ & $101^{\circ} 27^{\prime} 21^{\prime \prime} \mathrm{E}$ & $101^{\circ} 27^{\prime} 28^{\prime} \mathrm{E}$ & $101^{\circ} 27^{\prime} 35^{\prime} \mathrm{E}$ \\
& & 31 & 30,7 & 30,8 & 31,3 \\
2 & Temperature & 70,7 & 69,2 & 70 & 70,2 \\
3 & Humidity & 1,58 & 1,68 & 1,47 & 1,2 \\
4 & Wind velocity & 6,67 & 6,67 & 6,25 & 6,5 \\
5 & soil pH & & & &
\end{tabular}

(Source: Primary Data, 2019)

Station 1 is at position 0o30'83 "N 101o27'15" E, with soil $\mathrm{pH}$ averaging 6.67, air humidity ranges from $60 \%$ to $80 \%$, and wind speed is $1.58 \mathrm{~m} / \mathrm{s}$. Station 2 is at position 0o30'89 "N 101o27'21" E, with an average soil $\mathrm{pH}$ of 7, air humidity ranges from $63 \%$ to $79 \%$, and wind speed is $1.68 \mathrm{~m} / \mathrm{s}$. Station 3 is at position 0o30'90 "N 101o27'28" E, with an average $\mathrm{pH}$ of 6.25 , air humidity ranges from $63 \%$ to $75 \%$, and wind speed is $1.47 \mathrm{~m} /$ s. Station 4 is at position 0o30'95 "N 101027'35" E, with an average soil pH of 6.50, air humidity ranges from $61 \%$ to $79 \%$, and wind speed is $1.2 \mathrm{~m} / \mathrm{s}$. The air temperature in the morning ranges from $29 \mathrm{oC}$ to $33 \mathrm{oC}$, during the day it ranges from $29 \mathrm{oC}$ to $34 \mathrm{oC}$.

\section{Conclusions}

Based on the results of the overall analysis of the composition and structure of tree vegetation in the green edge area of Lancang Kuning Pekanbaru, it is known that tree-level vegetation is dominated by acacia (Acacia auriculiformis), ketapang (Terminalia catappa), angsana (Pterocarpus indicus), mahogany (Swietenia macrophylla), and greetings (Syzygium polyanthum). The five plants are found at each station.The appropriate tree category for the type of green edge tree in the edge wall barrier is Alstonia scholaris, because almost every observation station of this type has the highest Ks value among the other tree species, which is 69.89 at station 1, 68, 93 at station 2 , and 44.12 at station 3 . 


\section{References}

[1] Anonymous. 2002. RI Government Regulation Number 63 of 2002 concerning Urban Forests .---

----- 2002. Regional Regulation of Bandung City No. 10 of 2006 concerning the Pekanbaru City Spatial Planning.

[2] Anonymous. 2015. Selection of Urban Forest Plant Types. Accessed Friday, January 14, 2016.

[3] Buharman, Djam'an and Widyani. 2002. Atlas of Seeds of Indonesian Forest Plants Volume III. Bogor Seed Research and Development Center. Forestry Research and Development Agency -DF. N ... Special Publication Vol.2, No. September 8, 2002

[4] Buharman, DF. Djam'an and N. Widyani and Fatmawati IS. 2002. Atlas of Seeds of Indonesian Forest Plants Volume IV (Special Edition of Community Forest Plant Seeds). Bogor Seed Research and Development Center. Forestry Research and Development Agency. Special Publication Vol. 2, No. December 9, 2002

[5] Damayanti R. and Y.I. Look at. 2007. Guidelines for Identifying Less Known Wood Types. Center for Research and Development of Forest Products. Forestry Research and Development Agency. Bogor.

[6] Martawijaya A., I. Kartasujana, K. Kadir and SP. Among. 2005. Atlas of Indonesian Wood Volume I Mold Three (revised edition). Bogor Forestry Research and Development Agency. Ministry of Forestry. CV. Miranti Bogor. Martawijaya A., I. Kartasujana, YI. Mandang, SP.

[7] Tinambunan, R.S. 2006 Analysis of Green Open Space Needs in Pekanbaru City. Postgraduate. Bogor Bogor Agricultural Institute.

[8] Samsoedin, I. and T. Waryono. 2010. Urban Forests \& Tree Diversity in Jabodetabek. KEHATI Indonesia Biodiversity Foundation. Jakarta.

[9] Samsoedin, I. 2009. Integrative Research Plan (RPI) for 2010-2014 Fiscal Year: Development of Urban Forests / Urban Landscape (unpublished). Center for Forestry Socio Economic and Policy Research, Bogor.

[10] Samsoedin, I. and E. Subiandono. 2007. Urban Forest Development and Management. www.dephut.go.id/files/ Ismayadi.pdf. accessed 7 September 2011.

[11] Yulianto M. 2009. Analysis of Green Parks in Open Cities in Relation to Air Quality Conditions in City Parks. Master of Environmental Sciences Study Program. Graduate program. Pajajaran University Bandung.

[12] N. \& I. Yoga. Immune. 2011. RTH 30\% resolution (City) Green. PT. Main Scholarship Center for Members of IKPI Jakarta 2011. 